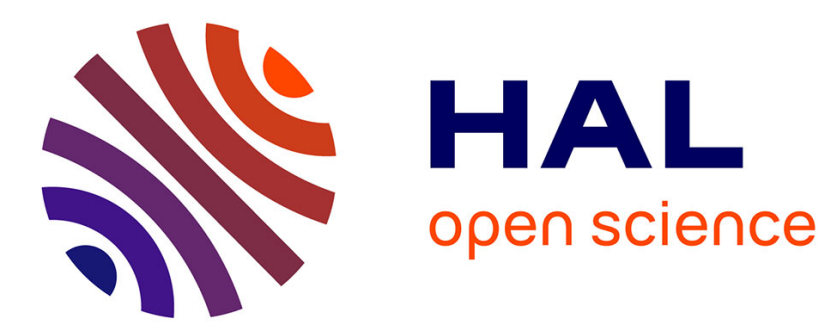

\title{
Functional income distribution and growth in Thailand: A post Keynesian econometric analysis
}

\author{
Bruno Jetin, Ozan Ekin Kurt
}

\section{To cite this version:}

Bruno Jetin, Ozan Ekin Kurt. Functional income distribution and growth in Thailand: A post Keynesian econometric analysis. Journal of Post Keynesian Economics, 2016, 39 (3), pp.334-360. 10.1080/01603477.2016.1202774 . hal-01484216

\section{HAL Id: hal-01484216 https://hal.science/hal-01484216}

Submitted on 13 Mar 2017

HAL is a multi-disciplinary open access archive for the deposit and dissemination of scientific research documents, whether they are published or not. The documents may come from teaching and research institutions in France or abroad, or from public or private research centers.
L'archive ouverte pluridisciplinaire HAL, est destinée au dépôt et à la diffusion de documents scientifiques de niveau recherche, publiés ou non, émanant des établissements d'enseignement et de recherche français ou étrangers, des laboratoires publics ou privés. 


\section{Functional income distribution and growth in Thailand: A Post Keynesian econometric analysis}

Bruno Jetin, Universiti of Brunei Darussalam and Université Paris 13 Sorbonne Paris Cité, bruno.jetin@ubd.edu.bn

OzanEkin Kurt, Université Paris 13 Sorbonne Paris Cité,ozanekinkurt@gmail.com

Abstract: The aim of this article is to analyze the effect of the income distribution between labor and capital on the growth performance of Thailand from a Post Keynesian view. It rests on the theoretical model of Bhaduri and Marglin (1990) to see if an increase in the labor income share has a sufficient positive effect on consumption to offset a negative effect on investment and export demand. In order to investigate the question empirically we adopt and develop the approach of Stockhammer et al. (2009). Several measures of the labor income share are calculated to take into account the fact that wage labor represents only half of the total labor force and check the robustness of our results. We also introduce a new treatment of external trade to better integrate the price competitiveness of Thailand. The econometric investigation shows that the growth regime is profit-led over the period 1970-2011 which shows that rebalancing the Thai economy will be difficult and requires an overall change of strategy going beyond a simple pro-labor policy.

Key Words: Thailand, functional distribution of income, Post Keynesian economics, growth, development

Thailand is a small, open economy that enjoyed a high rate of growth of around $6 \%$ over

the last five decades and became an upper-middle-income country in 2011 according to the World Bank's classification. A strong industrial push financed both by local and foreign investment promptedan intense structural change and set off a surge of industrial exports which became the primary engine of growth after Thailand had recovered from the Asian crisis of 1997-98. These facts are well-established and Thailand is typical of the second wave of export-led growth economies of Southeast Asia which followed Taiwan, South Korea, Hong Kong and Singapore.

The international crisis of 2008-09 and the uncertain recovery that followed show the limit of these export-led growth policies in particular now that the Chinese growth is decelerating. This raises the issue of rebalancing growth in favor of the domestic market not only for China but also for other Asian export-led growth countries like Thailand. A 
stronger role for the domestic market implies that an increase of household consumption offsets at least in part a decline in net exports. This article explores this possibility by looking at the relation between the functional income distribution and demand.Rebalancing growth to lessen the dependence on exports will be much easier if an increase in the labor income share has a sufficient positive effect on consumption to offset a negative effect on investment and exports. If it is the case, the demand is wage-led; otherwise it is profit-led. We apply the Post Keynesian model developed by Stockhammer et al. (2009)which precisely addresses this question.

This is the first application of such a model on Thailand, most of previous publications being based on advanced economies or large Asian economies like China and India which have different structural features. Our second contribution is the use of an original approach to calculate the labor income share in the context of a developing country. The objective is to include non-wage labor income in the labor share so that the full impact of a change in income distribution on growth is taken into account. The third contribution is the deepening of Stockhammer et al. (2009) model with a new treatment of international trade, which employsexport prices of competitor countries to explain exports and export prices of the country under investigation. This had not been done, in previous publications.

The article is organized as follows. Section 1 reviewsthe main characteristics of Thailand's macroeconomic performance. In Section 2 we compute various estimates of theThai labor income share, which for the major part includes non-wage labor, to test the robustness of our overall results. In Section 3, we present the theoretical model and the changes we introduce in the analysis of the foreign trade. In section 4 , we proceed to the 
econometric investigation and present the results.We find that Thailand is a profit-led economy because an increase in the labor income share has a strong negative effect on net exports which is not offset by a positive effect of the domestic demand. An increase in the labor income share has either a positive but small effect on household's consumption or a perverse (negative) effect, while in all cases it has no significant effect on investment. Section 5 concludes and draws some policy implications. A redistribution of income in favor of labor would have short-term negative effect on demand. This does not mean that Thailand should not rebalance its growth but that a mere income policy is not the best suited one to achieve this goal.

\section{Thailand's macroeconomic performance and structural change}

Along with the founders of ASEAN (Association of South East Asian Nations), Thailand belongs to the second generation of the newly industrialized countries which emerged at the turn of the nineties. Theyfollow the first generation of the four "dragons" (South Korea, Taiwan, Hong Kong and Singapore) which appeared at the turn of the eighties. Thailand was a poor country after the Second World War, but thanks to a 5.8\% average growth rate over the period 1960-2013, it is now part of the upper middle-income group of countries according to the World Bank with a gross national income per capita of $\$ 5,370$ in 2013below China $(\$ 6,560)$ and above Indonesia $\$ 3,580^{1}$.

After an initial phase of import-substitution policy from 1950 to 1977, policy makers adopted a policy of export-promotion growth based on an active support of industry.This led to a high rate of growth achieved thanks to a strong industrial push during a boom phase (1987-1996) characterized by a strong domestic investment rate which at the time induced a trade deficit of $4.4 \%$ of the GDP. Despite a solid increase of 
industrial exports, imports of intermediate and capital products were still higher. After the Asian crisis of 1997-98, which deeply affected Thailand with a 3.2\% recession of GDP in real terms, the recovery was prompted by a strong export growth. The trade balance became this time positive amounting to 5.3\% of GDP over the period 2000-2007. After the international crisis of $2008-09$, the trade surplus still accounted for $3.4 \%$ over the period 2010-2014 while investment never recovered its pre-Asian crisis level $^{2}$. For this reason, Thailand has been characterized as an export-led economy since the Asian crisis (Tharnpanich and McCombie, 2013, p 572; Jetin, 2012, p 15, Felipe and Lim, 2005, p 22).

Thailand has recently become a very open economy with itssum of exports and imports amounting to around $80 \%$ of GDP. Industry in the broad sense (ISIC C-E) now makes up $36 \%$ of GDP to be compared with a world average of $22 \%$, which places Thailand as an industrialized country ${ }^{3}$. This fast industrializationwas based on rapid capital accumulation initialized and managed by the State which later on triggered a cumulative growth cycle whereby demand growth promotes productivity gains via the Kaldor-Verdoon relation, and labor productivity gains in turn leads to an increase in demand (Naastepad and Storm, 2005). However, except for limited periods of time, Thai workers have never fully benefited from this growth cycle because their real income has lagged behind productivity gainscontributing toward achieving a high profit rate in the Thai economy as a whole and in particular in manufacturing (Jetin, 2012).

Nonetheless, the industrializationand the high growth rate it promoted induceda profound structural change of the Thai society, which is reflected in the reduction of poverty incidence, the change in employment structure, and the increase of income inequality.In 2013, absolute poverty headcount was close to $0 \%$ of the population 
according to the PPP\$ 1.25 international poverty line of the World Bank, and $10 \%$ according to the national poverty line in 2013 , down from respectively $17.2 \%$ and $65.2 \%$ in 1988 when the boom period kicked off ${ }^{4}$. The Gini coefficient of income inequality rose from 0.423 in 1962 to 0.527 in 2006 (Warr, 2009). Private sector employees, who accounted for $10 \%$ of total employment in $1969^{5}$ add up to $40 \%$ in 2014 . Adding government employees puts the share of employees to about $50 \%$ of total employment. This is still low in comparison with rich countries where employees represent around $80 \%$ or more of employment. This increase in the wage-earners' share was prompted by a sharp decline of family helpers in the farm sector to $13 \%$ in 2014 down from 50\% in 1969 and to a lesser extent by a decline of own-account farmers from $26 \%$ in 1969 to $18 \%$ in 2014.On the contrary, non-farm own-account workers' share grew from $5 \%$ to $15 \%$ of total employment over the period mostly because part of rural workers could not find a paid employmentand turned self-employed in cities instead ${ }^{6}$. The major part of these urban own-account workers provides services to wage workers so that their income is very dependent on the overall level of wages.A minor part is composed of high skilledindependent professionals (lawyers, physiciansetc.) like in rich capitalist countries.

To summarize, these deep and durable changes in the employment structure show that wage labor, if not dominant, already impulses the dynamics of the national demand and justifies the application of a Post-Kaleckian theoretical model developed for the rich capitalist countries.To this aim, our article analyzes the impact of a change in labor income share on growth in a broad sense; that is whatever the source of the labor income, be it wage or non-wage. The objective is to observe the effect of a change in the labor share on growth over the long period (1970-2011), which saw an intense structural 
change. We will also restrict the period under investigation to 1980-2011 when industrialization took off and a new working class of around 5 million blue collar workers in manufacturing and 12 million in the whole economy emerged ${ }^{7}$. These industrial workers, mostly concentrated in the Eastern seaboard of Thailand, have all the characteristics that Kalecki had in mind when he conceived a theoretical model where wages are the result of class struggle and bargaining. In the next section, we explain how we measure the labor share in various ways to either capture labor income in a comprehensive way or restrict it to wage earners only.

\section{Measuring the labor share: the Thai case}

Measuring the labor share always involves a degree of arbitrariness because the labor income stems from two categories of workers namely employees who earn a wage and own- account workers who earn a "mixed income" including both the returns on labor inputs and on capital investment. It is therefore necessary to estimate an adjusted labor share of income (ALS) that takes mixed income into account. In rich countries, where own-account work usually amounts to less than $10 \%$, attributing the average compensation of employees to own-account workers $\left(\mathrm{ALS}_{1)}\right.$ is common practice.

$\mathrm{ALS}_{1}=[($ Compensation of employees/Number of employees $) *$ (Number of employees + Own-account workers)] / GDP at factor cost

In Thailand where it amounts to $33 \%$ in 2014 , this adjustment leads to a strong bias because the vast majority of own-account workers are farmers or owners of small shops or street vendors in cities who usually earn less than the average wage. Most of them are non-registered or in other words are part of the informal economy. For these reasons, following Golin (2002) we calculated alternative $\operatorname{ALS}^{8}$ : 
$\mathrm{ALS}_{2}=($ Compensation of employees + Mixed income of own-account workers $) /$ GDP at factor cost

$\mathrm{ALS}_{3}=$ Compensation of employees / (GDP at factor cost - Mixed income)

$\mathrm{ALS}_{4}=$ Average of $\mathrm{ALS}_{2}$ and $\mathrm{ALS}_{3}$

To be as comprehensive as possible,we test all these possible adjustments to check the sensitivity of our econometric results on the choice of the measure of the labor'sshare. $\mathrm{ALS}_{4}$, is our preferred estimate because it avoids attributing all mixed income to the labor's share or hypothesizing that own-accounts workers have the same capital intensity than registered companies.Figure 1 presents the evolution of these labor shares in Thailand from 1969 to 2013.

Figure 1: Alternative measures of the labor's income share in Thailand, 1969 2013 here

Over the whole period $\mathrm{ALS}_{1}$ shows no clear long-term trend. The other adjusted labor sharesexperienced a downward trend over the period. In 2011, $\mathrm{ALS}_{4}$ was around 15\% below its level of 1969 .

The next section presents our theoretical model and tests the impact of a variation of these alternative labor sharesof income on growth.

\section{Theoretical Approach}

The theoretical model employed for the analysis of the growth regime in Thailand is a new version of the model by Stockhammer et al. (2009), which is based on the model of Bhaduri and Marglin (1990). Stockhammer et al. (2009) aim to find the effect of income distribution on consumption $(C)$, investment $(I)$, and net exports $(N X)$ and thus the total effect on aggregate demand $(Y)$. Those demand components are functions of income $(Y)$, 
labor share $(L S)$ and some control variables (denoted by $z$ )which are assumed to be exogenous. Government expenditures $(G)$ depend only on income. Then the aggregate demand can bewritten as:

$$
A D=C(Y, L S)+I\left(\mathrm{Y}, L S, \mathrm{z}_{\mathrm{I}}\right)+N X\left(Y, P, z_{N X}\right)+G\left(Y, z_{G}\right)
$$

where, $P$ is the (domestic) price level. The price level is also a function of wage share and other control variables. The prices considered in the model are domestic, export $\left(\mathrm{P}_{\mathrm{x}}\right)$ and import $\left(\mathrm{P}_{\mathrm{m}}\right)$ prices. Differentiation of the equation (1) with respect to $L S$ and goods market equilibrium condition $\left(Y^{*}=A D\right)$ gives:

$$
\frac{\mathrm{d} Y^{*}}{\mathrm{~d} L S}=\frac{h_{2}}{1-h_{1}}(2)
$$

where, $h_{1}=\partial C / \partial Y+\partial I / \partial Y+\partial N X / \partial Y+\partial G / \partial Y$ and $h_{2}=\partial C / \partial L S+\partial I / \partial L S+\partial N X / \partial L S$.For the stability of the model, the multiplier $1 /\left(1-h_{1}\right)$ should be positive. Then the sign of $h_{2}$,called private excess demand, determines the sign of the total derivative. It gives the change in demand due to a change in income distribution at a fixed level of income. Its sign cannot be determined without an empirical investigation since the partial derivatives have different signs. $\partial \mathrm{NX} / \partial \mathrm{Y}$ is equal to $\partial \mathrm{X} / \partial \mathrm{Y}-\partial \mathrm{M} / \partial \mathrm{Y}$; however, since there is no effect of domestic income on the exports, the term reduces to $-\partial \mathrm{M} / \partial \mathrm{Y}$. Since the government sector is excluded from the model the term $\partial G / \partial Y$ disappears. Eventually, $h_{1}$ becomes $\partial C / \partial Y+\partial I / \partial Y-\partial M / \partial Y$. If $d Y * / d L S$ turns out to be positive then the demand regimeis wageled; otherwise it is profit-led.For a given level of $Y$, the total effect of income distribution on the equilibrium demand can also be written as:

$$
\frac{\mathrm{d} Y^{*} / Y}{\mathrm{~d} L S}=\frac{h_{2}}{1-h_{1}}(3)
$$


which givesthe percentage change in the demand due to a one percent increase in the $L S$ as $h_{2}=\partial C / Y / \partial L S+\partial I / Y / \partial L S+\partial N X / Y / \partial L S .^{9}$

In this framework an important distinction is the one between domestic and open economy. In the former, if the consumption is more sensitive to a variation of the labor share than the investment, then the economy is wage-led, otherwise profit-led. Here it is assumed that an increase in labor share promotes total private consumption and discourages investment. The increasing labor share is supposed to stimulate the consumption of the workers more than that of the capitalists. ${ }^{10}$ If the economy is domestically wage-led, the entire economy might or not be wage-led depending on the elasticity of exports to the unit labor costs and hence the labor share. However, if the domestic sector is profit-led, the entire economy is necessarily profit-led.

In order to find the effect of the labor income share on the national income, the GDP components and the prices (domestic and export) are modeled as separate equations by Stockhammer et al. (2009). While maintaining their analytical framework for the domestic economy,for the analysis of tradewe opt for the approach by Mathis et al. (1988). These authors proposea framework of international competition which discriminates between price and non-price factors. We integrate some elements related to the international price competition. Thirlwall (2002), based on Kaldor(1970), also employs a similar exports function taking the price competitiveness into account(Hein, 2014, p. 148)

Regarding the domestic economy, Stockhammer et al. (2009) propose a consumption function of the form $C=\mathrm{f}(W, R)$, where $W$ is the labor income (or adjusted labor income) and $R$ is the capital income (or adjusted operating surplus). It is expected that workers have a higher propensity to consume than profit earners. The investment is 
modeled as $I=\mathrm{f}(Y, R)$ in order to concurrently take into account the scale of the economy and the profitability. We employ the same functions in our model.

As for the trade equations, firstly exports and imports are estimated as separate equations but they are also treated together as a single net exports equation. The exports function proposed by Stockhammer et al. (2009) is of the form $X=\mathrm{f}\left(Y_{f o r}, E, P_{x} / P_{m}\right)$, where $Y_{f o r}$ is the main foreign trade partners' weighted GDP, $\mathrm{E}$ is the exchange rate and $P_{x} / P_{m}$ is the ratio of export prices to import prices. The imports are modeled as $M=\mathrm{f}\left(Y, E, P / P_{m}\right)$. The combination of the two functions is $N X / Y=\mathrm{f}\left(Y, Y_{f o r}, E, R U L C\right)$ where $R U L C$ is the real unit labor costs and $U L C$ the unit labor costs.

We employ the same imports function but we exclude the exchange rate variable in the trade equations since all the macroeconomic magnitudes are in constant dollars in our model. In other words, the exchange rate is implicitly present in the model. The exports function is different in two points: firstly, it takes into account the export prices $P_{x}$ and that of the competitors $P_{x}^{c o m p}$, hence their ratio, which is the relative export prices $P_{x}^{\text {rel }}{ }^{11}$ This assumption is more appropriate since the importing countries compare the export prices of the exporting country by that of its competitors, not by the exporter's import prices. However, the impact of the import prices on the export prices is not neglected but captured via the domestic prices, which is also a function of unit labor costs. The domestic prices and $P_{x}^{\text {comp }}$ determine the $P_{x}$. The second difference is that exports are a function of the total (weighted) imports ${ }^{12}$ of the world, but not of the global GDP of the rest of the world. We do not use a net exports function.

As for the price equations, we employed the same domestic prices equation proposed by Stockhammer et al. (2009), which is modeled as $P=\mathrm{f}\left(P_{m}, U L C\right)$. The export 
prices are endogenized in our model in a price-maker-price-taker setting, as proposed by Mathis et al. (1988).Export prices are a function of the domestic prices and the weighted export prices of thecompetitors. The comparison of our model with that of Stockhammer et al. (2009) is in Table1.

\section{Table 1:Comparison of our model with that of Stockhammer et al. (2009) here}

We estimated our model over the period 1970-2011 and the sub-period 1980-2011. Detailed information on the variables and the data sources is in the appendice. The motivation behind using a subsample after 1980s is threefold. The first reason is the impact of what Dutt (1996) calls the agriculture constraint. Less developed countries (LDCs) are constrained by a low-productivity agriculture, whichdespite being overstaffed finds it hard to supply enough food for the population.According to Dutt, the more the agriculture constraint is relaxed and the country industrializes, the more Keynesian policies become relevant for LDCs. In Thailand, employment in agriculture represented around $80 \%$ of total employmentin 1970 , around $70 \%$ in 1980 and was down to $40 \%$ in $2011^{13}$. Among those working in agriculture, unpaid family helpers amounted to around $50 \%$ of employment in agriculture in 1970, 42\% in 1980, and was down to $17 \%$ in 2011 as many have left for jobs in industry or services which now accounts respectively for $19 \%$ and $40 \%$ of total employment. This tremendous process of structural change implies strong gains of labor productivity which was multiplied by 2.7 over the period 1970-2013 in agriculture, almost as much as in industry (2.8) and much more than in services $(1.6)^{14}$. It should be mentioned that, although subsistence farming plays an important role for poor farmers, especially those living from upland agriculture, cash crop is dominant in the plain and has allowed farmers to also engage increasingly into wage labor. Less than a quarter 
of rural people live exclusively from farming activities and around two thirds of their income is derived from off-farm activities (Walker, 2012). In 2013, the share of agriculture, industry and services in value added was respectively $9.5 \%, 43 \%$ and $47.5 \%{ }^{15}$. All these elements indicate that Keynesian policies have become more applicable in Thailand in the course of time.In this respect, the analysis of the subsample that covers the last three decades is expected to give more reliable results in terms of applicability of our post-Keynesian model to Thailand.

The second reason is to detect if the growth regime has changed after 1980 when the neoliberal hegemony began to dominate and the income distribution to deteriorate on a global scale. However, this type of a subsample study does not econometrically correspond to testing regime shift (from profit-led to wage-led, or vice-versa). We resort to such an econometric analysis since the number of the observations is limited and division of the sample into twowould not be sufficient to find robust results.A priori, we expect a more wage-led or less profit-led growth regime in the subsample of 1980-2011 compared to the full sample.

The third reason behind analyzing the subsample starting with 1980 is econometric. The Chow test suggests a structural break in some equations with some measures of the labor's income share at this year. This point will be explained in the section 4 , which is dedicated to the econometric estimations of the model.

\section{A review of empirical literature}

There are two approaches to testing Bhaduri-Marglin type of wage-led-profit-led models. The first type analyzes consumption, investment, exports and imports (or net exports) 
separately through single equations. Bowles and Boyer (1995) are the first to apply such a methodology to some developed countries. There is a vast literature on developed countries in this fashion. However, theoretical framework and equations vary. Among those,Naastepad and Storm (2006-7) examine eight OECD countries and conclude that the demand is wage-led in France, Germany, Italy, the Netherlands, Spain, and the United Kingdom, whereas profit-led in Japan and the USA. Hein and Vogel (2008), analyze Austria, France, Germany, the Netherlands, the UK and the USA. Stockhammer et al. (2009) apply the aforementioned model on the Euro area, considering it as a single country, and find that the whole area is wage-led.

The second type of models takes into account the interactions among the variables with the use of Vector Autoregressive Models (VAR). Gordon (1995a, 1995b) applies such a model, along with single equation estimations, to USA. Stockhammer and Onaran (2004) employ a structural VAR modelin their analysis of the USA, the UK, and France where they test a set of hypotheses.Onaran and Stockhammer (2005) use a similar approach for South Korea and Turkey and findsome evidence for wage-led regimes. More recently, Nishi (2012) examines the relationship among income distribution, debt ratio, and capital accumulation in Japan using a similar technique but a different modelthat distinguishes between debt-led and debt-burdened regimes.Hein (2014) provides an extensive literature review on both types of models along with the results of the analyses.

While most of the early literature focused on developed countries, a number of empirical studies have addressed the case of LDC recently. A pioneer workis that of Naastepad and Storm (2005) who analyzed the growth pattern regime of the East and the Southeast Asian countries. They build a different theoretical model derived from the 
Kaldor-Verdoon relation and found that these countries are profit-led.In the case of Thailand, the profit-led character is due to a positive effect of a rise in profitability on investment while the effect on net exports is not relevant.Onaran and Galanis (2014)have also realized a comprehensive analysis ofboth rich countries and LDCs over the period 1960-2007. ${ }^{16}$ They use the theoretical model and methodology of Stockhammer et al. (2009) but carry it one step further. They conduct an empirical research on 16 of the G20 countries to analyze the interactions among countries calculating global multipliers. Their model enables the examination of the impact of a simultaneous change of the labor income share at a global level on individual countries.For LDCs, their results show that they are profit-led contrary to most of rich countries which are wage-led with the exception of Australia and Canada.The profit-led countries have in common to be relatively small economies and thus very open to foreign trade. China is a special case. Although it is the second largest economy of the worldit is “... very strongly profit-led due to strong effect on exports and imports" (2012, op cit p 25). They conclude that the global economy is wage-led and in case of a worldwide race to the bottom in the labor share the global GDP contracts. Australia, China and South Africa are the only countries which maintain a positive but smaller growth. More recently, Molero-Simarro (2015) applies the Stockhammer et al. (2009) model on China for the period 1978-2007 and finds a negative effect of an increase of the profit share on consumption higher than the positive effect on investment. Over the whole period, the Chinese domestic economy is thus wage-led but when the positive effect of decreasing labor costs on net exports is taken into account the growth regime turns profit-led although of a lesser magnitude than in Onaran and Galanis' 
study.We will compare our results with these but before the estimation procedure of the model equations is explained in the next section.

\section{Estimation procedures and the Unit Root Tests}

We firstly examined the stationarity properties of the series, in logarithm, via Augmented Dickey Fuller (ADF) test. The highest order of integration is found to be 1 (i.e. I(1)). When all the series in the same equation are $I(1)$ we tested for cointegration among them via Engle-Granger (EG) method. ${ }^{17}$ When there was no cointegration, we ran an OLS in difference form. When all the variables in the same equation are stationary we applied the OLS method in differences, since we look for the short-run effects. We added autoregressive terms via Prais-Winsten (PW) method and pertinent dummy variables for the outliers when necessary. When the variables in the same equation are not of the same order, we employed Pesaran's (2001) Bounds test. Thus we can test cointegrationamong variables of different orders among which the maximum order of integration is $1^{18}$. When cointegration tests gave no sign of cointegration or were inconclusive, we applied the OLS method to the differences of the variables. As the model aims to capture the short-run dynamics between income distribution and the demand growth, lack of cointegration among the variables will not undermine the model.

After applying the relevant estimation technique, we check the robustness of the estimated equations by using the standard tests on residuals and coefficients. As for the residuals, we report DW test statistic and the probability values for White's heteroscedasticity test, the Autoregressive Conditional Heteroscedasticity (ARCH) test with one lag and the DoornikHansen normality test ${ }^{19}$. For the overall significance of the model and the parameters, probability values of the F-test, Chow $^{20}$, RESET test and CUSUM tests are presented. In 
order to check for the multicollinearity among the regressors, we report the VIF (Variance Inflation Factor $)^{21}$.

The ADF tests did not give straightforward results for the estimation of the equations. The unit labor costs and the price variables (except the domestic prices) turn out to be stationary and all the other variables are I(1) for the full sample at $5 \%$ significance level. In the next section we present the estimation results based on the procedure that we applied.

\section{Estimation of the model equations and results}

\section{Consumption}

We firstly tested cointegration among consumption and labor and capital income series via EGmethod since the $\ln C, \ln W_{i}$ andln $R_{i}$ series are all found to be I(1) according to the ADF tests.As we detected no cointegrationamong the series, with four alternatives of labor and capital income, we estimated the consumption equation in first differencesvia OLS as in the form $\Delta \ln C=$ constant $+e_{C W} \Delta \ln W_{i}+e_{C R} \Delta \ln R_{i}$, where $i$ is from 1 to $4 . e_{C W}$ and $e_{C R}$ represent the labor income and profit elasticities of consumption, respectively.A priori, we expect $e_{C W}$ the propensity to consume out of labor income, to be higher than $e_{C R}$, the propensityto consume out of profits, since workers spend a greater part of their income than profit earners. A shift of the income distribution in favor of labor will rise consumption expenditures. The higher the difference between $e_{C W}$ and $e_{C R}$ the higher the probability of the economy to be wage-led and vice-versa. Empirical research confirms that it is the casewith a difference between the marginal propensities around 0.4 , in accordance with the findings of the previous evidence as mentioned byLavoie and Stockhammer,(2013, p 22-24),(see Table 2). 


\section{Table 2:Consumption Equation Estimations Here}

$e_{C W}$ is higher than $e_{C R}$ for the four measures of income distribution ranging from 0.49 to 0.65 , whereas those of $e_{C R}$ are between 0.16 and $0.24^{22} . \mathrm{ALS}_{1}$, registers the highest difference between the two estimated elasticities(0.49) while for the three adjusted labor shares that include own-account workers,it is between 0.25 and 0.38 . One reason may be that own-account workers have a lower propensity to consume (Tobin, 1971, p 84) either for precautionary motives due to the risky nature of their business or because they earn higher revenues and have a higher propensity to save like rich households and entrepreneurs. In order to estimate the impact of a change in income distribution on consumption for the period under consideration, we transform the elasticities into marginal effects and take the difference of them with the formula: $\partial C / Y / \partial L S=e_{C W} C / W$ $e_{C R} C / R$, where $\mathrm{C} / \mathrm{W}$ and $\mathrm{C} / \mathrm{R}$ are sample averages or the values of the corresponding ratios at a certain point of the time period considered. We obtain different resultsat the sample mean, at the beginning and the end of the period of the sample as seen in Table 3.

\section{Table 3: Change in Consumption due to a $1 \%$ increase of the Labor Income Share}

\section{here}

When the whole sample is considered, the effect is positive for $\mathrm{ALS}_{1}$, which imputes the average compensation to own-account workers, and negative for the three other adjustments which include the income of own-account workers.It is suggested that a $1 \%$ increase of the labor income share leads to a $0.24 \%$ rise of consumption when $\mathrm{ALS}_{1}$ is considered and a decrease of consumption ranging from 0.07 to $0.42 \%$ for the other adjusted labor shares. The reason is that in the last three cases, the labor income hike leads to a decline of capitalists' consumption of a greater magnitude than the rise of workers' 
consumption.Conversely, an increase of the profit share would induce a rise of consumption. This confirms that as far as consumption is concerned, demand is profit-led in Thailand when own-account workers' income is taken into consideration.We observe that a redistribution of income in favor of labor is more likely to raise consumption at the end of the period which means that consumption is getting more wage-led.

The possibility of sucha phenomenon, though in contradiction with the a priori hypothesis $\partial C / \partial L S>0$, has recently been discussed within the Post Keynesian framework by Stockhammer and Stehrer (2011) and Kapeller and Schütz (2015). The former authors, in their empirical analysis based on the Goodwin and Kalecki models, name occurrence of a such effect as 'perverse consumption differential' and observe it in theUK, Ireland, Australia and the USA. They state that their framework does not explain this phenomenon but add that missing variables might be the underlying reason. They suggest that e.g. strong wealth effects in consumption might engender such a case. The latter authors develop the 'perverse effects' on theoretical grounds drawing from the 'conspicuous consumption' concept of Veblen. They show, in two different cases, that, a decrease in the labor's income share might have different impacts within the labor class if the class is composed of heterogeneous workers. In their model, in which the labor class is composed of two types of workers, a decrease in the labor's income share is only passed on one type of the workers (type 2), while the other's share stays constant (type 1). In such a setting, the type 2 workers, facing a reduction in their wages, try to keep up with the consumption levels of the type 1 workers through increasing their consumptions with or without debt burden. Thus the relative consumption concerns of the type 2 workers might lead to two cases of consumption-driven profit-led regimes. 
Some features of the income distribution in Thailand fit well with these arguments.Ourfindings might be a sign of such a segregation within the labor class for instance between those working in the formal economy which enjoy usually higher income and those working in the informal economy. More broadly, the income inequality is high with a Gini coefficient of income around 0.5 (Jitsuchon, 2014, p. 5) and households are highly indebted to maintain or improve their level of consumption in particular of durable goods such as housing and cars. For the richer households, a wealth effect of 0.02 to 0.03 was estimated for 2010 which was of the same magnitude as countries like the USA, Italy or Spain(Rungcharoenkitkul, 2011). Thiscould explain the perverse effect in consumption once mixed income is included in the estimate of the labor's share. These characteristics are possible candidates to explain the observed profitled pattern in consumption but further investigation of the personal distribution of income in Thailand is required to confirm their macroeconomic effects on demand.

\section{Investment}

The $\ln I, \ln Y$, andln $R_{i}$ series are I(1) according to the ADF tests. Since the cointegration tests did not give significant results, we estimated a difference equation instead,as $\Delta \ln I=$ constant $+e_{I Y} \Delta \ln Y+e_{I R} \Delta \ln R_{i}$ where $i$ is from 1 to 4 . $e_{I Y}$ and $e_{I R}$ represent the income and profit elasticities of investment, respectively. We estimatedthe equations with a dummy variable controlling for the Asian financial crisis of $1997^{23}$. This variable captures the sharp fall in investment after the 1997 crisis, which constitutes an outlier of the growth rate of the $\ln I$ series. The results of the regressions for the four labor income shares are shown in Table 4.

Table 4: Investment Equation Estimation here 
The results demonstrate that $e_{I Y}$ lies in the range 2.12-2.40. However, $e_{I R}$ is insignificant for the four alternative measures of profits. The a priori hypothesis on the positive impact of profits on investment is not validated.This result isnot surprising when compared to those foundon developing countries in the literature.Onaran and Galanis (2014) find no significant impact of profit share onprivateinvestment in several developing countries like China, India, and Turkey. As for China, they note that MoleroSimarro (2015) and Wang (2009) find a significant positive effect of profits on total investment. Itis mentioned that the objectives of the state and private enterprises are different, although an increase in profits would provide more funds for financing investment. It should also be noted that financialization, which is not taken into account in our model, plays an important role in the relation between profits and investment. Onaran et al. (2011), in their article on the USA, finda positive significant effect of the former on the latter, after deducting the interest and dividends from the gross operating surplus.The insignificance of the profits in the investment functionis in line with the statement of Bhaduri and Marglin that "investment, particularly in long-lived fixed capital equipment, is likely to respond more cautiously to a change in profit margin/share compared to consumption" (1990, p. 385).

\section{Exports}

The ADF tests show that $\ln X, \ln M_{w 1}$ and $\ln M_{w 2}$ series are I(1); however, $\ln P_{x r e l}$ turns out to be stationary. Since the variables are integrated of different orderswe appliedBounds test. This test rejected cointegrationamongthe exports, the total world imports (of the two alternative measures) and the relative export prices series. Consequently, we estimated a difference equation instead of the form $\Delta \ln X=$ constant $+\beta \Delta \ln M_{w j}+\kappa \Delta \ln P x^{r e l}$, where $j$ is the 
index for the two measures of the world imports. $\beta$ and $\kappa$ represent the world imports and the price elasticities of the exports, respectively. The results of the regressions are in Table 5.

\section{Table 5:Exports Equation Estimations here}

We obtain identical results with the two alternative measures of the world imports. The coefficients have almost the same magnitudes and they are highly significant. The growth of the world demand, measured by a simple or weighted sum of the exports of Thailand, by $1 \%$ leads to $0.3 \%$ growth in the exports of Thailand. The impact of international price competition is more substantial. A $1 \%$ increase of the relative prices of the exported products shrinks the exports by around $0.7 \%$.

\section{Imports}

The imports equation has similar characteristics with the exports in terms of econometric properties of the variables. $\ln M$ and $\ln Y$ are $I(1)$ but $\ln P / P m$ is stationary. Pesaran's (2001)Bounds test shows no sign of cointegration. We estimated the equation in difference form as $\Delta \ln M=$ constant $+\rho \Delta \ln Y+\gamma \Delta \ln P / P_{m}$ where $\rho$ and $\gamma$ are the income and (relative) price elasticities of imports, respectively.The results of the regression is displayed in Table 6.

\section{Table 6: Imports Equation Estimations here}

Both coefficients are highly significant. A 1\% increase in domestic demand raises imports by $1.67 \%$. The imports are even more sensitive than the exports to the relative prices:an increase of $P / P_{m}$ by $1 \%$ tends to increasethe imports by around $0.9 \%$. This high sensitivity to the price of imported goods can be explained by the share of import content of exports which has increased recently. Whereas the import content of export was $12 \%$ in 
1995, it more than doubled reaching $30.1 \%$ in 2008 because of the growing importance of electronics and automobile components which are part of global value chains (Poonpatpibul et al. 2009, p 17-18). This is a strong constraint on a stimulus policy of domestic demand. However, thisdependence of a part of the imports to exports, is not taken into consideration by our model. Stockhammer et al. (2011) employ an income distribution-growth model, for Germany, into which the import content of the exports isintegrated. Whenever the exports decline,e.g. due to an increase of the export prices, imports of some goods, majorly the semi-finished products, are expected to decline accordingly. Integrating this dimension into the income distribution-growth models prevents the overestimation of the impact of the labor income share on net exports. ${ }^{24}$

\section{Domestic Prices}

The ADF test indicates that $\ln P$ series are non-stationary, but the two explanatory variables $\ln P_{m}$ and the four measures of $\ln U L C$ are stationary. We estimated a difference equation as $\Delta \ln P=$ constant $+\eta \Delta \ln U L C_{i}+\mu \Delta \ln P_{m}$, where $i$ takes values from 1 to 4 according to the alternative measures of income distribution. $\eta$ and $\mu$ are the elasticities of unit labor costs and import prices of the domestic prices, respectively. We included two dummy variables in the regressions in order to control for the 1973 petrol crisis ${ }^{25}$ and the 1997 Asian financial crisis, which had unprecedented inflationary and deflationary effects on the evolution of the domestic prices in Thailand, respectively.Addition of the dummy variables also enabled correction of heteroscedasticity that arose due to the two crises. We present the estimation results in Table 7.

\section{Table 7: Domestic Prices Equation Estimations here}

The estimations display the variability of the significance and magnitude of the 
coefficients depending on the unit labor cost measure, which depends on the type of adjustment. The coefficient $\eta$ is in the range $0.55-0.67$, while $\eta$ is not significant with respect the first type of labor income adjustment and lies between $0.17-0.19^{26}$. The dummy variables reflect the impact of the drastic price increases and decreases, while in some specifications they are not significant at $5 \% .{ }^{27}$ Chow test suggests that there is a structural break at 1980 .

Export Prices

As already stated, $\mathrm{ADF}$ test indicates that $\ln P$ series are non-stationary; however, the $\ln P_{x}$ and $\ln P_{x}^{c o m p}$ series are stationary. We estimated a difference equation as $\Delta \ln P_{x}=$ constant + $\lambda \Delta \ln P+\tau \Delta \ln P_{x}^{\text {comp }}$, where $\lambda$ and $\tau$ are the relevant elasticities. The estimations are reported in Table 8.

\section{Table 8: Export Prices Equation Estimations here}

Since the 1973 petrol crisis ceiled the export prices, we added the dummy variable, which is already used in the domestic price regressions. Addition of this variable not only solved the heteroscedasticity problem, but also being highly significant,it displays the inflationary impact of the petrol shock on the export prices. ${ }^{28}$. The results show that a $1 \%$ increase of the domestic prices leads to a $0.31 \%$ increment of the export prices while the effect of the foreign export prices on the latter is $0.41 \%$. These empirical finding suggest that Thailand is a price-taker country since $\tau$ is higher than $\lambda$. As in the domestic prices equation, a structural break is present at 1980 .

In the next section we combine the theoretical model with the estimations of the coefficients obtained from the regressions in order to characterize the growth regime of Thailand. 


\section{Calculation of the Effect of Income Distribution on Growth}

The overall effect on an increase of the labor income share on economic growth is by the multiplier in the equation 3, as mentioned in the section on the theoretical framework. We used the coefficients (elasticities) extracted from the regressions and the sample (19702011) mean of the related ratios for the period considered in the calculations. The model implies that the sign of the private excess demand $\left(h_{2}\right)$ characterizes the growth regime and $h_{l}$ determines its magnitude.

The first element of the $h_{1}$ is the marginal effect $\partial C / \partial Y$, which is equal to the multiplication ofe $\mathrm{CY}_{\mathrm{CY}}$, the elasticity of $C$ with respect to $Y$, and the sample average of the ratio of $C$ to $Y$. $\mathrm{e}_{C Y}$ is not directly derived from the regressions. Stockhammer et al. (2009) simply use the sum of $e_{C R}$ and $e_{C W}$ for $\mathrm{e}_{\mathrm{CY}}$, since the consumption function is of type Cobb-Douglas; however, Onaran and Galanis (2014) calculate a weighted sume $e_{C R}(R / Y)+$ $e_{C W}(W / Y)$, where $R / Y$ and $W / Y$ are sample averages of shares of capital and labor income, respectively. Since the weighted sum, which underestimates the income elasticity, is always lower than $e_{C W}$, we opt for the former approach. ${ }^{29}$ The second and the third elements $\partial I / \partial Y$ and $\partial M / \partial Y$ are equal to the multiplication of the elasticities that are directly obtained from the regressions and the sample averages of the relevant ratios.

As for the calculation of $h_{2}, \partial I / Y / \partial L S$ is equal to $-e_{I R}(I / R)\left(Y_{f} / Y\right) . \partial X / Y / \partial L S$ is calculated by the formula[ $[\lambda \eta /(1-\eta)](X / Y) / L S .{ }^{30}$ In the same manner, $\partial M / Y / \partial L S$ is calculated as $\left[\gamma \eta_{C} /(1-\eta)\right](M / Y) / L S .^{31}$ The effect of a $1 \%$ increase in the labor income share on the net exports is shown in Table9

\section{Table9:Total Effect of a $1 \%$ increase of the labor income share on demand for the full sample (1970-2011)}

The results clearly indicate that the economy is profit-led with respect to four 
different measures of the labor income share. The effect of a $1 \%$ increase in the labor income share shrinks the GDP by around $2 \%$ for most of the adjusted labor income shares. In the case of $\mathrm{ALS}_{2}$, the decline in GDP approaches to 3\%. Our final results show that the total effect of a change in the distribution of income is the highest found until now by the literature. In the case of China, which is also an example of an export-led economy, Galanis and Onaran (2014, op cit) using what we called $\mathrm{ALS}_{1}$ in our article found that an increase of $1 \%$ of the profit share has a total effect of $1.57 \%$ on growth, the highest total effect of their sample while Molero-Simarro(2015, op cit) found a small total effect of $0.011 \%$.Our resultsare robust to various estimates of the labor income shareand reveals the strong dependency of Thailand on foreign markets due to its high export (45\%) and import $(52 \%)$ to GDP ratios ${ }^{32}$ and its sensitivity to price competitiveness in the past decades. These characteristics of a small open economy combine to explain that the profit-led character of Thailand depends above all on the strong negative effect of a change in the labor income share on net exports (for instance -1.29, with respect to $\mathrm{ALS}_{1}$ ) and in particular on imports (1.07, again with respect to $\mathrm{ALS}_{1}$ ) which reflects the limit of the development model of Thailand. Future research should explore further this topic and bring more insights to give a comprehensive explanation of the dependence of Thailand on imports.

A Sub Period Analysis: 1980-2011

As mentioned above, analyzing the sub-period 1980-2011 enables cross checking the results obtained for the entire sample. Due to space limitations, we skip the intermediate stages of the econometric investigation and present the results in Table10.

Table 10: Total Effect of a $1 \%$ increase of the labor income share on demandfor the subsample (1980-2011)

As for the consumption function, we obtain similar results as in the analysis of the entire 
sample. However, globally, the negative effects are smaller in absolute value for $A L S_{2}$ to $A L S_{4}$ and the positive effects are higher for $A L S_{1}$. This reflects the greater influence of wage labor in the economy and confirms that demand is becoming less profit-led.Still, we cannot claim a regime shift after 1980. The results of the regressions are almost identical for the investment functions. The trade equations, except fort the calculations based on $\mathrm{ALS}_{1}$, point that the export-led pattern is still present but weaker. The overall character of the growth regime persists to be profit-led, however, a one percent increase of labor income share resultsin a 1 to $1.5 \%$ decrease of the GDP at market prices, except for ALS $_{1}$ which gives an identical result as in the entire sample. Overall, the results validate our expectations of a weaker profit-led regime.

\section{Conclusion and Policy Implications}

This article explored the possibility to rebalance the Thai growth with a policy of domestic market stimulus based on an increase of the labor income share. Our investigation shows that,other things being equal, such a policy would lead to a short-term decreaseof the GDP of around $2 \%$ because the demand regime is profit-led: an increase in the labor share has a strong and negative impact on net exports which is not offset by a positive impact on consumption while it has no effect at all on investment. This result is in accordance with the conclusions of other researches on East Asian countries and more generally on small open economies (Onaran and Galanis, 2013). In our case, it can be explained by the features of the Thai economy, which combined a relatively small domestic market and a large export sector. The Thai industrial apparatus is geared towards exports, especially the industrial companies that are part of global value chains. For these companies, which include many subsidiaries of multinationals, wages are most of all viewed as a cost and 
not primarily as a source of domestic demand. A wage hike will not increase the sales of computers, cell phones or TV screens,by much in Thailand and therefore investment in these sectors.However, it will impact more significantly the cost of production and hence the competitiveness of Thai exports. This illustrates a point made by Lavoie and Stockhammer $(2013,19-20)$ : the income distributional policy must be consistent with the economic regime of the economy. A single policy of labor share increase in a profit-led economic regime is bound to fail. This does not mean that the Thai growth regime can be maintained without any change. The results of the econometric analysis must be interpreted with caution as regards the policy implications. The profit-led character reflects the structure of the Thai economy and can be seen as a historical resume of the coevolution of the labor share and the output level of Thailand. The econometric results cannot be extrapolated by suggesting that a continuous decline of the labor's share due to income suppression will have the same positive impact on net exports in the short or long run. Moreover, partial dependence of the imports to exports, which is not integrated into our model, overestimates the profit-led character of the economy. In a future research, this aspect should be taken into account.

The investment function deserves to be discussed in depth from a theoretical point of view. The model does not take into account the accumulation of capital, which is employed in a typical Kaleckian investment function, and its long-term effects. However, since our research is restrained to short-term demand growth, using such an investment function is not inconsistent. It might be argued that the series span a too long period for estimation of a short-term model. If monthly or quarterly data series were available, the equations could have been estimated for much shorter periods, in terms of years, since the 
number of observations would increase. Then the econometric estimations would have been much more consistent with the theoretical model. Another point to be addressed is financialization, especially issues concerning household debts and rentiers, who receive dividends and interest payments. These elements are also important for determination of consumption. Integration of rentier class in the model would be more complete for consumption and investment functions, as in the study by Onaran et al. (2011). However a problem arises: such data is hard to come by for developing countries like Thailand.Last but not least, the structural change is not captured by the investment function. The industrial policies led by the state, e.g. industry-specific credits, might have short and long term impacts on investment decisions. While not ignorable, these issues should be addressed and integrated in a more in-depth research within the post-Keynesian framework.

Despite these limitations, our article points to the need for change. The export-led growth pattern of Thailand may have been coherent with the global economy in the past, but the uncertain recovery of the 2008-09 international crisis, the emergence of new lowcost competitors of Thailand, and the slowdown of China's growth show that the global economy is no more supportive of ever increasing export sales. In these new circumstances, an export-led growth economy like Thailand must consider rebalancing its growth because one cannot imagine that an ever decreasing labor income share will be the solution.

The real solution is to rebalancethe Thai economy away from export and towards the domestic market by implementing a broad set of economic and social policies that will change the overall structure of the economy. The objective is to shift from a profit-led to a 
wage-led economy based on the domestic market. However, our results show that a mere wage-policy is not sufficient to achieve this goal and should be accompanied by policies aiming structural change in favor of promoting domestic market.

\section{REFERENCES}

Bhaduri, A. and Marglin, S. 'Unemployment and the real wage: the economic basis for contesting political ideologies', Cambridge Journal of Economics, December 1990, 14(4), 375-93.

Bowles, S. and Boyer, R. 'Wages, aggregate demand, and employment in an open economy: an empirical investigation' In Epstein, G. A. and Gintis, H. M. (eds.), Macroeconomic Policy after the Conservative Era: Studies in Investment, Saving and Finance,Cambridge, Cambridge University Press, 1995, 143-71,.

Dutt, A. 'The Role of Keynesian Policies in Semi-industrialized Countries: theory and evidence from India', International Review of Applied Economics, 1996, 10(1), 127-40.

Gordon, D. "Growth distribution and the rules of the game: social structuralist macro foundations for a democratic economic policy" In Epstein, G. and Gintis, H. (eds.), Macroeconomic Policy after the Conservative Era: Studies in Investment, Saving and Finance, Cambridge, Cambridge University Press, 1995a,335-83.

------------. "Putting the horse (back) before the cart: disentangling the macro relationship between investment and saving" In Epstein, G. and Gintis, H. (ed.), Macroeconomic Policy after the Conservative Era. Studies in Investment, Saving and Finance, Cambridge, Cambridge University Press, 1995b, 57-108.

Ederer, S. 'Competition-oriented Wage Policy and Its Effects on Aggregate Demand in the Netherlands' WIFO (Austrian Institute of Economic Research) Working Paper, available for download athttp://www.wifo.ac.at/jart/prj3/wifo/resources/person_dokument/person_dokument.jart? publikationsid=31462\&mime type=application/pdf, 2008, 312 .

Feenstra, Robert C., Robert Inklaar and Marcel P. Timmer, "The Next Generation of the Penn World Table" available for download at www.ggdc.net/pwt, 2013.

Felipe J., Lim J. "Export or Domestic-led Growth in Asia?" Asian Development Bank, ERD Working Paper, 2005, 69.

Gollin, D. “Getting Income Shares Right”, Journal of Political Economy, April 2002, $110(2), 458-74$.

Hein, E. Distribution and Growth after Keynes: A Post-Keynesian Guide. Cheltenham, UK: Edward Elgar Publishing, 2014. 
Hein, E. and Vogel, L. 'Distribution and growth reconsidered: empirical results for six OECD countries', Cambridge Journal of Economics, 2008, 32, 479-511.

Jetin, B. 'Distribution of income, labour productivity and competitiveness: is the Thai labour regime sustainable?' Cambridge Journal of Economics, 2012, 36(4), 895-917.

Jitsuchon, S. 'Income Inequality, Poverty and Labor Migration in Thailand'. Singapore Economic Review, 2014, 59 (1).

Kaldor, N. 'The case for regional policies', Scottish Journal of Political Economy, 1970, $17,337-348$.

Kapeller, J. and Schütz, B. 'Conspicuous Consumption, Inequality and Debt: The Nature of Consumption-driven Profit-led Regimes' Metroeconomica, 2015, 66(1), 51-70.

Lavoie, M. and Stockhammer E, 'Wage-led Growth: Concept, Theories and Policies' in M. Lavoie and E. Stockhammer (ed.), Wage-Led Growth an Equitable Strategy for Economic Recovery. Basingstoke, UK: Palgrave Macmillan, 2013,13-39,

Mathis, J. ; Mazier, J. ; and Rivaud-Danset, D. La competitivité industrielle. Paris, France: Dunod, 1988.

Molero-Simarro, R. 'Functional distribution of income, aggregate demand, and economic growth in the Chinese economy, 1978-2007', International Review of Applied Economics, 2015, 1-20.

Naastepad, C. W. M. and Storm, S. 'Strategic factors in economic development: East Asian industrialization 1950-2003',Development and Change,2005, 36(6), 1059-1094.

Naastepad, C. W. M. and Storm, S. 'OECD demand regimes (1960-2000)', Journal of Post-Keynesian Economics, Winter 2006-7, 29(2), 213-48.

Nishi, H. 'Structural VAR analysis of debt, capital accumulation, and income distribution in the Japanese economy: a Post Keynesian perspective',Journal of Post Keynesian Economics, Summer 2012, 34(4), 685-712.

Onaran, Ö. and Galanis"Is Aggregate Demand Wage-led or Profit-led? A Global Model" In M. Lavoie and E. Stockhammer (ed.), Wage-Led Growth An Equitable Strategy for Economic Recovery. Basingstoke, UK: Palgrave Macmillan, 71-99, 2013.

----o-----o. G. 'Income Distribution and Growth: A Global Model'

Environment and Planning A', 2014, 46(10), 2489-2513.

Onaran, Ö. and Stockhammer, E. 'Two different export-oriented growth strategies:accumulation and distribution in Turkey and in South Korea', Emerging Markets Finance and Trade, 2005, 41, 65-89. 
Onaran, Ö., Stockhammer, E. and Grafl, L. 'Financialisation, income distribution and aggregate demand in the USA', Cambridge Journal of Economics, 2011, 35, 637-661.

Pesaran, M. H.; Shin,Y.; and Smith, R.J.. "Bounds testing approaches to the analysis of level relationships." Journal of applied econometrics, 2001, 16(3), 289-326.

Poonpatpibul C., Vorasangasil N., Junetrakool M. and Prasitdechsakul P. Is There an Alternative to Export-led Growth for Thailand? Bank of Thailand Discussion Paper, Bank of Thailand, 2009, DP/08/2009.

Razmi, A. Balance-of-Payments-Constrained Growth Model: The Case of India,Journal of Post-Keynesian Economics, 2005, 27(4), 655-687.

Rungcharoenkitkul, P. Wealth Effect and Consumption in Thailand, Bank of Thailand Discussion Paper, Bank of Thailand, 2011, DP/01/2011.

Stockhammer E. and Stehrer, R. 'Goodwin or Kalecki in Demand? Functional Income Distribution and Aggregate Demand in the Short Run'. Review of Radical Economics, 2011, 20(10), 1-17.

Stockhammer, E., Onaran, Ö. and Ederer, S. 'Functional Income Distribution and Aggregate Demand in the Euro-area', Cambridge Journal of Economics, 2009, 33(1), 13959.

Stockhammer, E.; Hein, E.; and Grafl, L. 'Globalization and the effects of changes in functional income distribution on aggregate demand in Germany', International Review of Applied Economics, 2011, 25(1), 1-23.

Tobin J. Essays in Economics: Consumption and Econometrics. Vol 2. Cambridge MA and London, MIT Press, 1971.

Tharnpanich, N. and McCombie, J.S.L. 'Balance-of-payments constrained growth, structural change, and the Thai economy', Journal of Post-Keynesian Economics, Summer 2013, 35(4), 569-97.

Thirlwall, 'The Nature of Economic Growth'. Cheltenham, UK and Northampton, MA, USA, Edward Elgar Publishing, 2002.

Walker, A. 'Thailand's Political Peasants. Power in the Modern Rural Economy'. Madison, University of Wisconsin Press, 2012, p 277.

Wang, P. 'Three Essays on Monetary Policy and Economic Growth in China', Unpublished PhD. Thesis, University of Ottawa, 2009.

Warr, P. 'Poverty Reduction through Long-Term Growth: the Thai Experience', Asian Economic Papers, 8(2), 2009, 27-51. 


\section{Appendix}

Data sources

\begin{tabular}{|c|c|c|c|}
\hline Database & Institution & Date of Access & Note \\
\hline $\begin{array}{l}\text { PWT 8.0: Penn World } \\
\text { Table version } 8.0\end{array}$ & $\begin{array}{l}\text { Center for International } \\
\text { Comparisons of } \\
\text { Production, Income and } \\
\text { Prices, University of } \\
\text { Pennsylvania and } \\
\text { University of Groningen }\end{array}$ & September 2013 & $\begin{array}{l}\text { Prepared by Feenstra } \\
\text { et al. }(2013)\end{array}$ \\
\hline $\begin{array}{l}\text { CHELEM: } \\
\text { International trade } \\
\text { flows, balances of } \\
\text { payments and world } \\
\text { revenues }\end{array}$ & $\begin{array}{l}\text { CEPII : Centre d'Etudes } \\
\text { Prospectives et } \\
\text { d'Informations } \\
\text { Internationales (France) }\end{array}$ & April 2014 & $\begin{array}{l}\text { We used the } \\
\text { CHELEM } \\
\text { International Trade } \\
\text { Database }\end{array}$ \\
\hline $\begin{array}{l}\text { WDI: World } \\
\text { Development } \\
\text { Indicators }\end{array}$ & WB: World Bank & April 2014 & \\
\hline $\begin{array}{l}\text { NIPA: National } \\
\text { Income and Product } \\
\text { Accounts of Thailand }\end{array}$ & $\begin{array}{l}\text { NESDB: National } \\
\text { Economic and } \\
\text { Social Development } \\
\text { Board of } \\
\text { Thailand }\end{array}$ & January 2015 & $\begin{array}{l}\text { Calculations are based } \\
\text { on the article by Jetin } \\
\text { (2012) and updated in } \\
2015 \text { by him. }\end{array}$ \\
\hline Labor Force Survey & $\begin{array}{l}\text { National Statistical } \\
\text { Office (NSO) of } \\
\text { Thailand }\end{array}$ & January 2015 & $\begin{array}{l}\text { For long-term } \\
\text { consistency, all } \\
\text { employment data are } \\
\text { from the third quarter } \\
\text { of each year. }\end{array}$ \\
\hline
\end{tabular}

All data used in the article are annual over the 1970-2011 period.

\section{Variables}

$C, I, X, M, Y$ : In constant 2005 dollars and retrieved from the WDI database.

$W, R$ : Adjusted sum of labor and capital incomes are calculated by multiplying the adjusted labor share by the GDP at factor costs in constant dollars.

$P_{x}, P_{x}^{\text {comp }}, P_{x r e l}$ and $P_{m}$ : Normalized export and import price indices of Thailand and its 
competitors are from the PWT 8.0 database. $P_{x}^{\text {comp }}$ is the weighted price index of the trade partners of Thailand, where the weights are the shares of exports of Thailand to the countries in its total exports. $P_{x}^{r e l}$ is simply the ratio of $P_{x}$ to $P_{x}^{\text {comp }}$.

$M_{w}$ : We used two alternatives for the world demand. The first one, denoted as $M_{w 1}=$ $\sum_{i}^{N} \alpha_{i} M_{i}$, where $\alpha_{i}$ is the share of exports of Thailand towards the country $i$, i.e. $\alpha_{i}=$ $\frac{X_{i}}{\sum_{i}^{N} X_{i}}$, and $M_{i}$ is the total imports of the country $i$. Alternatively, a simple sum of the imports of the rest of the world, denoted as $M_{w 2}=\sum_{i}^{N} M_{i}$, is used in the estimations.

\section{Unit labor costs}

Unit labor costs $(U L C)$ is the ratio of the nominal compensation of workers to real output, i.e. real GDP at market prices.We obtain the real unit labor cost $(R U L C)$ if the labor compensation is also in real terms. The RULC and the $L S$ are slightly different. While the former is the ratio of the real labor compensation to real GDP at market prices $(\mathrm{Y})$, the latter is the share of the (real) labor compensation in (real) GDP at factor costs $\left(\mathrm{Y}_{\mathrm{f}}\right)$.

Price deflator

The price deflator $P$ used in the estimations is not the one calculated in local currency (bahts) but its conversion into constant 2005 dollars. It is equivalent to multiplication of the domestic price deflator by $\mathrm{PPP}_{2005}$, the Purchasing Power Index for 2005 and its division by $\mathrm{E}$, the exchange rate. Then it is normalized such that its value in 2005 is equal to 1 . This deflator is then used to calculate the unit labor costs.

Derivation of Multipliers

The impact of $L S$ on exports is found indirectly through combining the domestic price, export price and exports equations. At the first stage, replacing ULC by its definition P.LS. $Y_{f} / Y$ in the domestic price equation, we obtain the following reduced equation:

$$
\ln P=\text { constant }+\eta_{C} /\left(1-\eta_{C}\right) \cdot \ln L S+\eta /(1-\eta) Y_{f} / Y+\mu /(1-\eta) \ln P_{m}
$$

Secondly, we replace this reduced equation in the export prices equation and obtain another reduced equation: 


$$
\ln P_{x}=\text { constant }+\lambda \eta_{C} /(1-\eta) \ln L S+\lambda \eta /(1-\eta) Y_{f} / Y+\lambda \mu /(1-\eta) \ln P_{m}+\ldots
$$

Finally replacing this equation in the exports equation and taking the partial derivative of $\mathrm{X}$ with respect to LS gives us the multiplier formula $[\kappa \lambda \eta /(1-\eta)] X / L S$. Dividing this multiplier by $\mathrm{Y}$ we obtain $\partial X / Y / \partial L S$. The imports multiplier $\partial M / Y / \partial L S$ is derived in a similar way. 


\section{Tables and Figures}

Figure 1: Alternative measures of the Labor Share of Income in Thailand, 1969 - 2013
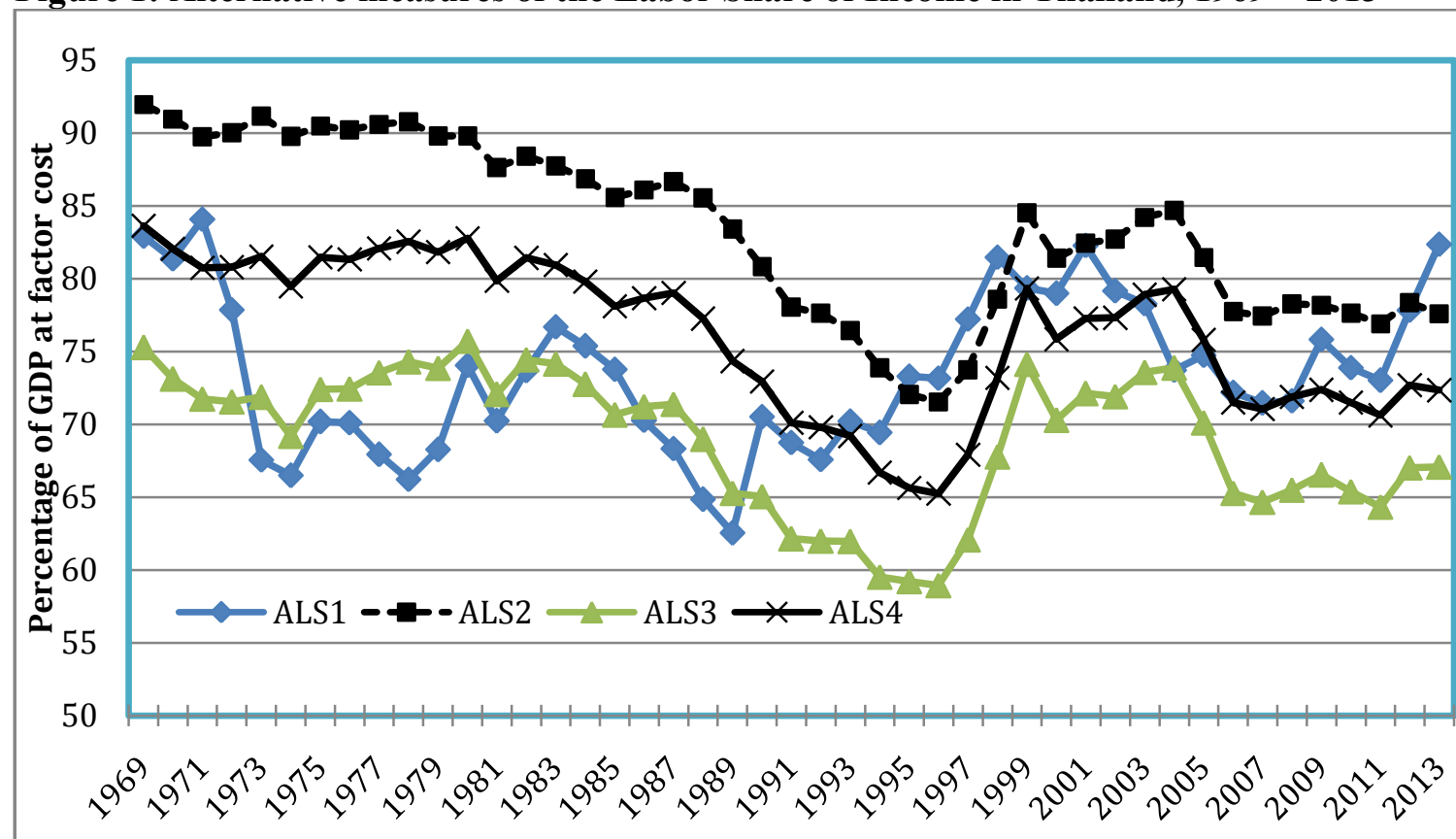

Source: Authors' calculations with data from NESDB and NSO (Employment, third quarter)

Table 1: Comparison of our model with that of the Stockhammer et al. (2009)

\begin{tabular}{lll}
\hline Dependent Variable & Stockhammer et al. (2009) & Our model \\
\hline Consumption & $C=\mathrm{f}(W, R)$ & $C=\mathrm{f}(W, R)$ \\
Investment & $I=\mathrm{f}(Y, \mathrm{R})$ & $I=\mathrm{f}(Y, \mathrm{R})$ \\
Exports & $X=\mathrm{f}\left(Y_{f o r}, E, P_{x} / P_{m}\right)$ & $X=\mathrm{f}\left(M_{w}, P_{x} / P_{x}{ }^{\text {comp }}\right)$ \\
Imports & $M=\mathrm{f}\left(Y, E, P / P_{m}\right)$ & $M=\mathrm{f}\left(Y, P / P_{m}\right)$ \\
Net Exports & $N X / Y=\mathrm{f}\left(Y, Y_{\text {for }}, E, R U L C\right)$ & - \\
Domestic Prices & $P=\mathrm{f}\left(P_{m}, U L C\right)$ & $P=\mathrm{f}\left(P_{m}, U L C\right)$ \\
Export Prices & $P_{x}=\mathrm{f}\left(P_{m}, P\right)$ & $P_{x}=\mathrm{f}\left(P, P_{x}^{c o m p}\right)$ \\
\hline
\end{tabular}

Notes: $M_{w}$ are the two versions of total imports of the world. See the appendix for the details. Since the labor shares are calculated in different ways, we have four alternative series of $W, R$ and $U L C$, i.e. $i$ is from 1 to 4. 
Table 2: Consumption

\begin{tabular}{|c|c|c|c|c|c|c|}
\hline \multirow{2}{*}{$\begin{array}{l}\text { Dependent variable: } \Delta \ln C \\
\text { Regressors }\end{array}$} & \multicolumn{2}{|l|}{$\mathrm{i}=1$} & \multicolumn{2}{|c|}{$i=2$} & \multicolumn{2}{|l|}{$i=3$} \\
\hline & Coefficient & t-ratio & Coefficient & t-ratio & Coefficient & t-ratio \\
\hline Constant & 0 & 0.69 & 0.01 & 1.11 & 0.01 & 1.19 \\
\hline$\Delta \ln \mathrm{W}_{\mathrm{i}}$ & $0.65 * * *$ & 9.05 & $0.55^{* * *}$ & 6.66 & $0.49^{* * *}$ & 6.27 \\
\hline$\Delta \ln R_{i}$ & $0.16^{* * *}$ & 7.92 & $0.17 * * *$ & 5.96 & $0.24 * * *$ & 6.85 \\
\hline \multicolumn{7}{|l|}{ Diagnostics } \\
\hline $\mathrm{R}^{2}$ & 0.76 & & $0.6 \mathrm{C}$ & & 0.69 & \\
\hline Adjusted $\mathrm{R}^{2}$ & 0.74 & & 0.67 & & 0.67 & \\
\hline DW statistic & 1.87 & & 1.76 & & 1.75 & \\
\hline Heteroscedasticity test & 0.72 & & 0.05 & & 0.71 & \\
\hline ARCH test (1 lag) & 0.94 & & 0.17 & & 0.22 & \\
\hline Normality test & 0.61 & & 0.52 & & 0.89 & \\
\hline F-test & 0.00 & & 0.00 & & 0.00 & \\
\hline Chow test (Break at 1980) & 0.05 & & 0.22 & & 0.27 & \\
\hline RESET test (with squares) & 0.22 & & 0.07 & & 0.05 & \\
\hline CUSUM test & 0.82 & & $0.8 \mathrm{~s}$ & & 0.99 & \\
\hline Highest VIF & 1.05 & & 1.00 & & 1.00 & \\
\hline
\end{tabular}

Notes: ${ }^{* * *},{ }^{* *}$ and $*$ represent 1,5 and $10 \%$ of significance levels, respectively.

Table 3: Change in Consumption due to a $1 \%$ increase in the Labor Income Share

$\begin{array}{lrrrr} & \text { ALS1 } & \text { ALS2 } & \text { ALS3 } & \text { ALS4 } \\ 1970 & -0.03 & -1.23 & -0.22 & -0.51 \\ \text { Mean } & 0.24 & -0.42 & -0.07 & -0.20 \\ 2011 & 0.22 & -0.02 & 0.06 & 0.01\end{array}$


Table 4: Investment Equation

\begin{tabular}{|c|c|c|c|c|c|c|}
\hline \multirow{2}{*}{$\begin{array}{l}\text { Dependent variable: } \Delta \ln I \\
\text { Regressors }\end{array}$} & \multicolumn{2}{|l|}{$\mathrm{i}=1$} & \multicolumn{2}{|c|}{$\mathrm{i}=2$} & \multicolumn{2}{|c|}{$i=3$} \\
\hline & Coefficient & t-ratio & Coefficient & t-ratio & Coefficient & t-ratio \\
\hline Constant & -0.07 & -4.45 & -0.07 & -4.47 & $-0.07 * * *$ & -4.31 \\
\hline$\Delta \ln Y$ & $2.40 * * *$ & 9.44 & $2.12 * *$ & 8.32 & $2.14 * * *$ & 7.89 \\
\hline$\Delta \ln R i$ & -0.07 & -1.23 & 0.12 & 1.54 & 0.11 & 1.01 \\
\hline D1997-1998 & $-0.20 * * *$ & -4.56 & $-0.18 * * *$ & -3.89 & $-0.18 * * *$ & -3.90 \\
\hline \multicolumn{7}{|l|}{$\rho^{\mathrm{a}}$} \\
\hline \multicolumn{7}{|l|}{ Diagnostics } \\
\hline $\mathrm{R}^{2}$ & \multicolumn{2}{|c|}{0.89} & \multicolumn{2}{|c|}{0.89} & \multicolumn{2}{|c|}{0.90} \\
\hline Adjusted $\mathrm{R}^{2}$ & \multicolumn{2}{|c|}{0.88} & \multicolumn{2}{|c|}{0.88} & \multicolumn{2}{|c|}{0.88} \\
\hline DW statistic & \multicolumn{2}{|c|}{1.72} & \multicolumn{2}{|c|}{1.72} & \multicolumn{2}{|c|}{1.75} \\
\hline Heteroscedasticity test $^{\mathrm{b}}$ & \multicolumn{2}{|c|}{0.21} & \multicolumn{2}{|c|}{0.51} & \multicolumn{2}{|c|}{0.02} \\
\hline $\mathrm{ARCH}_{\text {test }}{ }^{\mathrm{b}}(1 \mathrm{lag})$ & \multicolumn{2}{|c|}{0.51} & \multicolumn{2}{|c|}{0.25} & \multicolumn{2}{|c|}{0.29} \\
\hline Normality test ${ }^{\mathrm{b}}$ & \multicolumn{2}{|c|}{0.28} & \multicolumn{2}{|c|}{0.07} & \multicolumn{2}{|c|}{0.10} \\
\hline F-test ${ }^{b}$ & \multicolumn{2}{|c|}{0.00} & \multicolumn{2}{|c|}{0.00} & \multicolumn{2}{|c|}{0.00} \\
\hline Chow test ${ }^{\mathrm{b}}$ (Break at 1980) & \multicolumn{2}{|c|}{0.53} & \multicolumn{2}{|c|}{0.43} & \multicolumn{2}{|c|}{0.46} \\
\hline RESET test $^{\mathrm{b}}$ (with squares) & \multicolumn{2}{|c|}{0.13} & \multicolumn{2}{|c|}{0.12} & \multicolumn{2}{|c|}{0.11} \\
\hline CUSUM test $\mathrm{t}^{\mathrm{b}}$ & \multicolumn{2}{|c|}{0.09} & \multicolumn{2}{|c|}{0.07} & \multicolumn{2}{|c|}{0.08} \\
\hline Highest VIF & 2.08 & & 2.1 & & 2.34 & \\
\hline
\end{tabular}

Notes: ${ }^{* *}, * *$ and $*$ represent 1,5 and $10 \%$ of significance levels, respectively.
a. $\rho$ is the parameter of PW method.
b. Probability values of the corresponding tests 
Table 5: Exports Equation

\begin{tabular}{|c|c|c|c|c|}
\hline \multirow{2}{*}{$\begin{array}{l}\text { Dependent variable: } \Delta \ln \mathrm{X} \\
\text { Regressors }\end{array}$} & \multicolumn{2}{|l|}{$\mathrm{j}=1$} & \multicolumn{2}{|l|}{$j=2$} \\
\hline & Coefficient & t-ratio & Coefficient & t-ratio \\
\hline Constant & $0.06^{* * *}$ & 4.41 & $0.06^{* * *}$ & 3.35 \\
\hline$\Delta \ln \mathrm{Mw}_{\mathrm{j}}$ & $0.30 * * *$ & 2.9 & $0.30 * * *$ & 3.15 \\
\hline$\Delta \ln P_{\mathrm{x}}^{\text {rel }}$ & $-0.67 * * *$ & -2.93 & $-0.66 * * *$ & -3.28 \\
\hline AR2 & & & $0.35 * *$ & 2.26 \\
\hline \multicolumn{5}{|l|}{ Diagnostics } \\
\hline $\mathrm{R}^{2}$ & 0.26 & & 0.32 & \\
\hline Adjusted $\mathrm{R}^{2}$ & 0.23 & & 0.28 & \\
\hline DW statistic & 1.91 & & 1.80 & \\
\hline Heteroscedasticity test $^{\mathrm{a}}$ & 0.38 & & & \\
\hline ARCH test ${ }^{a}(1 \mathrm{lag})$ & 0.45 & & 0.25 & \\
\hline Normality test $^{\mathrm{a}}$ & 0.28 & & 0.77 & \\
\hline F-test ${ }^{a}$ & 0.00 & & 0.00 & \\
\hline Chow test ${ }^{\mathrm{a}}$ (Break at 1980$)$ & 0.12 & & & \\
\hline RESET test $^{\mathrm{a}}$ (with squares) & 0.07 & & & \\
\hline CUSUM test $^{\mathrm{a}}$ & 0.96 & & & \\
\hline Highest VIF & 1.06 & & 1.04 & \\
\hline
\end{tabular}

Notes: $* * *, * *$ and $*$ represent 1,5 and $10 \%$ of significance levels, respectively.

a. Probability values of the corresponding tests

Table 6: Imports Equation

\begin{tabular}{|c|c|c|}
\hline $\begin{array}{l}\text { Dependent variable: } \Delta \ln \mathrm{M} \\
\text { Regressors }\end{array}$ & Coefficient & t-ratio \\
\hline Constant & -0.01 & -0.58 \\
\hline$\Delta \ln Y$ & $1.67 * * *$ & 4.51 \\
\hline$\Delta \ln \mathrm{P} / \mathrm{P}_{\mathrm{m}}$ & $0.91 * * *$ & 3.91 \\
\hline \multicolumn{3}{|l|}{ Diagnostics } \\
\hline $\mathrm{R}^{2}$ & 0.63 & \\
\hline Adjusted $\mathrm{R}^{2}$ & 0.61 & \\
\hline DW statistic & 2.25 & \\
\hline Heteroscedasticity test ${ }^{\mathrm{a}}$ & 0.62 & \\
\hline $\mathrm{ARCH}_{\text {test }}{ }^{\mathrm{a}}(1 \mathrm{lag})$ & 0.89 & \\
\hline Normality test $^{\text {a }}$ & 0.59 & \\
\hline F-test $^{\mathrm{a}}$ & 0.00 & \\
\hline Chow test ${ }^{\text {a }}$ (Break at 1980) & 0.94 & \\
\hline RESET test $^{\mathrm{a}}$ (with squares) & 0.23 & \\
\hline CUSUM test ${ }^{\text {a }}$ & 0.58 & \\
\hline Highest VIF & 1.25 & \\
\hline
\end{tabular}

Notes: $* * *, * *$ and $*$ represent 1,5 and $10 \%$ of significance levels, respectively.

a. Probability values of the corresponding tests 
Table 7: Domestic Prices Equation

\begin{tabular}{|c|c|c|c|c|c|c|c|c|}
\hline Dependent variable: $\Delta \ln P$ & \multicolumn{2}{|l|}{$\mathrm{i}=1$} & \multicolumn{2}{|l|}{$\mathrm{i}=2$} & \multicolumn{2}{|l|}{$\mathrm{i}=3$} & \multicolumn{2}{|l|}{$\mathrm{i}=4$} \\
\hline Regressors & Coefficient & t-ratio & Coefficient & t-ratio & Coefficient & t-ratio & Coefficient & t-ratio \\
\hline Constant & 0.01 & 1.58 & 0 & 1.3 & $0.01 *$ & 1.76 & 0.01 & 1.59 \\
\hline$\Delta \operatorname{lnULC} C_{i}$ & $0.63 * * *$ & 6.13 & $0.67 * * *$ & 10.6 & $0.55^{* * *}$ & 7.77 & $0.60 * * *$ & 9.03 \\
\hline$\Delta \ln \mathrm{P}_{\mathrm{m}}$ & 0.11 & 1.12 & $0.17 * *$ & 3.07 & $0.19 * * *$ & 2.3 & $0.18^{* *}$ & 2.31 \\
\hline D1973-1974 & $0.09 * * *$ & 3.42 & & & $0.06 * *$ & 2.13 & $0.05 *$ & 1.91 \\
\hline D1997-1998 & $-0.09 * * *$ & -3.16 & $-0.07 * * *$ & -2.77 & $-0.11 * * *$ & -4.01 & $-0.09 * * *$ & -3.48 \\
\hline$\rho^{\mathrm{a}}$ & & & 0.30 & & 0.23 & & 0.30 & \\
\hline Diagnostics & & & & & & & & \\
\hline $\mathrm{R}^{2}$ & 0.84 & & 0.91 & & 0.88 & & 0.90 & \\
\hline Adjusted $\mathrm{R}^{2}$ & 0.83 & & 0.90 & & 0.87 & & 0.89 & \\
\hline DW statistic & 2.11 & & 1.80 & & 1.95 & & 1.93 & \\
\hline Heteroscedasticity test ${ }^{b}$ & 0.38 & & & & & & & \\
\hline ARCH test ${ }^{\mathrm{b}}(1 \mathrm{lag})$ & 0.70 & & 0.78 & & 0.35 & & 0.57 & \\
\hline Normality test $\mathrm{t}^{\mathrm{b}}$ & 0.20 & & 0.71 & & 0.78 & & 0.77 & \\
\hline F-test ${ }^{b}$ & 0.00 & & 0.00 & & 0.00 & & 0.00 & \\
\hline Chow test ${ }^{\mathrm{b}}$ (Break at 1980) & 0.03 & & & & & & & \\
\hline RESET test $^{\mathrm{b}}$ (with squares) & 0.00 & & & & & & & \\
\hline CUSUM test ${ }^{\mathrm{b}}$ & 0.86 & & & & & & & \\
\hline Highest VIF & 2.09 & & 2.04 & & 1.75 & & 1.91 & \\
\hline
\end{tabular}

Notes: ${ }^{* * *},{ }^{* *}$ and $*$ represent 1,5 and $10 \%$ of significance levels, respectively.

a. $\rho$ is the parameter of PW method.

b. Probability values of the corresponding tests 
Table 8: Export Prices

\begin{tabular}{|c|c|c|c|c|c|}
\hline $\begin{array}{l}\text { Dependent variable: } \Delta \ln P_{x} \\
\text { Regressors }\end{array}$ & Coefficient & t-ratio & Coefficient & t-ratio & Coefficient \\
\hline Constant & 0.01 & 0.65 & 0.01 & 1.06 & 0.00 \\
\hline$\Delta \ln \mathrm{P}$ & $0.42^{* * *}$ & 3.32 & $0.31 * * *$ & 2.89 & $0.42 * * *$ \\
\hline$\Delta \ln P_{x}^{\text {comp }}$ & $0.51^{* * *}$ & 3.16 & $0.41^{* * *}$ & 3.1 & $0.39^{* * *}$ \\
\hline D1973-1974 & & & $0.13 * * *$ & 4.39 & $0.12 * * *$ \\
\hline D1997-1998 & & & & & 0.05 \\
\hline \multicolumn{6}{|l|}{ Diagnostics } \\
\hline $\mathrm{R}^{2}$ & 0.65 & & & & 0.78 \\
\hline Adjusted $\mathrm{R}^{2}$ & 0.63 & & & & 0.75 \\
\hline DW statistic & 1.74 & & & & 1.72 \\
\hline Heteroscedasticity test ${ }^{\mathrm{a}}$ & 0.03 & & & & 0.74 \\
\hline ARCH test ${ }^{\mathrm{a}}(1 \mathrm{lag})$ & 0.98 & & & & 0.56 \\
\hline Normality test ${ }^{\mathrm{a}}$ & 0.05 & & & & 0.39 \\
\hline F-test ${ }^{\mathrm{a}}$ & 0.00 & & & & 0.00 \\
\hline Chow test ${ }^{\mathrm{a}}$ (Break at 1980$)$ & 0.00 & & & & 0.00 \\
\hline RESET test ${ }^{a}$ (with squares) & 0.00 & & & & 0.03 \\
\hline CUSUM test ${ }^{\mathrm{a}}$ & 0.40 & & & & 0.08 \\
\hline Highest VIF & 1.97 & & & & 3.67 \\
\hline
\end{tabular}

Notes: ${ }^{* * *},{ }^{* *}$ and $*$ represent 1,5 and $10 \%$ of significance levels, respectively.

a. Probability values of the corresponding test 
Total 9:Total Effect of a 1\% increase of the labor income share on demandfor the full sample (1970-2011)

\begin{tabular}{|c|c|c|c|c|c|c|c|c|c|c|c|c|}
\hline & \multicolumn{3}{|c|}{ ALS1 } & \multicolumn{3}{|c|}{ ALS2 } & \multicolumn{3}{|c|}{ ALS3 } & \multicolumn{3}{|c|}{ ALS4 } \\
\hline & 1970 & Mean & 2011 & 1970 & Mean & 2011 & 1970 & Mean & 2011 & 1970 & Mean & 2011 \\
\hline Consumption & -0.03 & 0.24 & 0.22 & -1.23 & -0.43 & -0.02 & -0.22 & -0.07 & 0.06 & -0.51 & -0.20 & 0.01 \\
\hline Investment & 0.00 & 0.00 & 0.00 & 0.00 & 0.00 & 0.00 & 0.00 & 0.00 & 0.00 & 0.00 & 0.00 & 0.00 \\
\hline Exports & -0.08 & -0.22 & -0.40 & -0.08 & -0.22 & -0.45 & -0.06 & -0.16 & -0.32 & -0.07 & -0.18 & -0.37 \\
\hline Imports & 0.51 & 1.07 & 1.09 & 0.46 & 1.14 & 1.04 & 0.57 & 0.84 & 1.24 & 0.51 & 0.95 & 1.13 \\
\hline Net Exports & -0.59 & -1.29 & -1.50 & -0.54 & -1.36 & -1.48 & -0.63 & -1.00 & -1.57 & -0.58 & -1.13 & -1.50 \\
\hline Private excess demand & -0.62 & -1.05 & -1.27 & -1.77 & -1.80 & -1.51 & -0.85 & -1.07 & -1.50 & -1.08 & -1.33 & -1.49 \\
\hline Total effect & -1.59 & -1.98 & -1.23 & -3.76 & -2.63 & -1.54 & -1.59 & -1.62 & -1.07 & -2.24 & -1.95 & -1.25 \\
\hline
\end{tabular}

Total 10: Total Effect of a $1 \%$ increase of the labor income share on demand for the subsample (1980-2011)

\begin{tabular}{lccccccccccccc} 
& \multicolumn{3}{c}{ ALS1 } & \multicolumn{3}{c}{ ALS2 } & \multicolumn{3}{c}{ ALS3 } & \multicolumn{3}{c}{ ALS4 } \\
\cline { 2 - 14 } & 1980 & Mean & 2011 & 1980 & Mean & 2011 & 1980 & Mean & 2011 & 1980 & Mean & 2011 \\
\hline Consumption & 0.46 & 0.43 & 0.40 & -0.99 & 0.07 & 0.07 & -0.28 & -0.01 & 0.09 & -0.51 & -0.12 & 0.03 \\
Investment & 0.00 & 0.00 & 0.00 & 0.00 & 0.00 & 0.00 & 0.00 & 0.00 & 0.00 & 0.00 & 0.00 & 0.00 \\
Exports & -0.08 & -0.18 & -0.30 & -0.05 & -0.11 & -0.20 & -0.03 & -0.10 & -0.14 & -0.04 & -0.11 & -0.18 \\
Imports & 0.54 & 1.48 & 1.09 & 0.44 & 0.89 & 1.09 & 0.44 & 0.79 & 1.04 & 0.48 & 0.85 & 1.13 \\
Net Exports & -0.62 & -1.67 & -1.40 & -0.49 & -1.00 & -1.29 & -0.48 & -0.89 & -1.18 & -0.52 & -0.96 & -1.31 \\
Private excess demand & -0.16 & --1.24 & -0.99 & -1.48 & -0.94 & -1.22 & -0.76 & -0.90 & -1.08 & -1.03 & -1.08 & -1.28 \\
Total effect & -1.02 & -1.95 & -1.25 & -2.45 & -1.08 & -0.94 & -1.12 & -1.11 & -0.63 & -1.67 & -1.28 & -0.87 \\
\hline
\end{tabular}




\section{Notes}

${ }^{1}$ In current prices Atlas method (for further details, see World Development Indicators, the World Bank).

2 Over the period 1970-1985, the ratio of private investment to GDP was on average $20.3 \%$ and $27.3 \%$ for total GFCF. During the boom period (1986-96) it was respectively $29.5 \%$ and $36.8 \%$. After the Asian crisis (1997-98) and over the period 1999-2013, it fell to respectively $15.5 \%$ and $21.4 \%$. Authors' calculations with data from NESDB.

${ }^{3}$ Over the same period (average of 2010-2013), the share of industry (which includes mining, manufacturing and utilities) in GDP was $42 \%$ in China, deemed as the factory of the world, 35\% in Indonesia the biggest economy of ASEAN and 33.3\% in the whole South-East Asia (source: United Nations, National Accounts Main Aggregates Database, GDP and its breakdown at constant 2005 prices in US dollars).

${ }^{4}$ Source: World Development Indicators, the World Bank.

51969 is the first year for which detailed data is available. Source: National Statistical Office of Thailand, Labor Force Survey, various years. For data consistency we used the third quarter of each year, which was the sole available in the early years.

${ }^{6}$ Source: Authors' estimations with data from the Labor Survey of the National Statistical Office (NSO) of Thailand, various issues.

${ }^{7}$ Source: authors' estimates with NSO data.

${ }^{8} \mathrm{~A}$ methodological note detailing data issues, estimates of the adjusted labor shares and econometric results is available on request to the authors.

${ }^{9}$ The empirical calculations will be based on this version of the private excess demand.

${ }^{10}$ Our empirical findings in the next section show that this is not the case for all but one measures of the labor's share that we calculated.

${ }^{11}$ Thirlwall (2002, chap 4) employs a similar exports function. He uses domestic prices foreign prices ratio instead of relative export prices. Ederer (2008) employs the same exports function as ours, however, export prices are a function of domestic and imports prices in his model, while in our model the export prices depend on along with domestic prices, (weighted) export prices of competitor countries instead of import prices.

12Razmi (2005) also uses a weighted sum of world imports instead of world income in the estimation of the exports equation in order to test the Balance of Payments Constrained Growth Model for India.

${ }^{13}$ Authors' estimations with data for employment by industry taken from the National Statistical Office of Thailand. We use data from the third quarter of each year for consistency over the period and to avoid seasonal fluctuations.

${ }^{14}$ Labor productivity is calculated by the authors as value added in the relevant sector, in constant US\$ 2005 (source: World Development Indicators, 2014) divided by data for employment by industry published by the National Statistical Office of Thailand, third quarter.

15 Source: World Development Indicators.

${ }^{16}$ In their study, LDCs are Argentina, China, India, Korea, Mexico, South Africa and Turkey and for these countries the period covered is 1970-2007.

${ }^{17}$ The results of the ADF, EG and which are not presented due to space limitations, are available on request.

18. Three outcomes are possible due to the nature of the test. The series might be cointegrated, they might be all stationary or no conclusion can be drawn from the test.

${ }^{19}$ Although normality is not a must for the residuals we report the probability values of the DoornikHansen test. Gelman and Hill (2007) underline that '[t]he regression assumption that is generally least important is that the errors are normally distributed. In fact, for the purpose of estimating the regression line (as compared to predicting individual data points), the assumption of normality is barely important at all.'

${ }^{20}$ Since we hypothesize a structural break starting from 1980s we applied the Chow test to that year. The same test is also conducted for the mid-sample date 1990, however, no signal of a break was detected. 
${ }^{21}$ We report the highest VIF of the regressors of a given regression. Values higher than 10 point at multicollinearity.

22 These estimations are comparable with those of Onaran and Galanis (2014) who get elasticities in the range of 0.316 for Turkey to 0.845 for South Korea with a labor share calculated like ALS ${ }_{1}$.

${ }^{23}$ This variable takes the value 1 for the years 1997 and 1998, 0 otherwise. We also added the year 1998 since the impact of the crisis persisted.

${ }^{24}$ Since we do not have enough data for the import content of the exports of Thailand, we cannot address this issue in our current work.

25 This variable takes the value 1 for the years 1973 and 1974, 0 otherwise. We included the year 1974 since the effect of the petrol crisis remained.

${ }^{26} \mathrm{e}_{\text {PulC }}$ is 0.35 (Turkey)-0.77 (China) for the developing countries in the estimations of Onaran and Galanis (2014) ., while ePPm is not significant for India, Mexico and China and for the others ranges between 0.12 (South Africa)-0.36 (Argentina).

27 We excluded D1973-1974 from the estimations with $\mathrm{ULC}_{2}$ since it was not significant.

${ }^{28} \mathrm{We}$ also tried a third specification by including the dummy variable for the Asian crisis, but this variable wasnot significant. We opt for the second estimation for our calculations

${ }^{29}$ The classical Keynesian equation $\Delta \ln C=$ constant $+e_{C Y} \Delta \ln Y$ gives an income elasticity of 0.88 . Although this coefficient cannot be directly used in our model, it gives an idea about the magnitude of the coefficient. Our estimates lie between 0.72 and 0.81 .

${ }^{30}$ See the appendix on the derivation of multipliers.

${ }^{31}$ Here it is implicitly assumed that domestic and imported goods are perfectly substitutable.

32 In constant 2005 dollars. Authors' calculations based on World Development Indicators, the World Bank. 